\title{
Some Linguistic Features of the Old Kashmiri Language of the Bānasūrakath $\bar{a}$
}

Saartje Verbeke

Ghent University/Research Foundation Flanders (FWO)

Blandijnberg 2

B-9000 Gent

Belgium

Saartje.Verbeke@UGent.be

\section{Abstract:}

The Bāṇāsūrakathā is a sharada manuscript in Old Kashmiri composed by Avtar Bhatt, dated between the $14^{\text {th }}-16^{\text {th }}$ century. It retells the love story of the demon Bāna's daughter Ușā with Krishna's grandson Aniruddha, and the ensuing fight between Bāṇa and Krishna, as it is found in the Harivamśapurāna. This article focuses on the linguistic features of the Old Kashmiri language in which this manuscript is composed. Old Kashmiri belongs to the Early New Indo-Aryan language stage, a stage crucial for a number of syntactic developments which determined the Indo-Aryan languages of today. First, the language found in the Bāṇāsūrakathā is situated among the attestations of Old Kashmiri found in other manuscripts. The language is younger than that of the Mahānāya-Prakāśa, but older than the language used in the Lallā-Vakyāni. Second, a number of linguistic features of Old Kashmiri are presented, such as the case marking and the verb agreement. Third, the article focuses on the phenomenon of pronominal suffixation, well-known in Modern Kashmiri, but not present in Apabhramśa. It is shown that the first traces of pronominal suffixation already exist in the Bāṇāsūrakathā, but their use is not yet grammatically fixed.

Key words: Old Kashmiri, Bāṇasūrakathā, case marking, agreement, linguistics, literature 


\section{Introduction}

In the Old Kashmiri Bāṇāsurakathāa (BK), the poet Avtar Bhatt (or Bhattāvatara) retells the puranic story of the fight between the demon Bāṇa and Krishna; and the love story of Krishna's grandson Aniruddha and Bāṇa's daughter Uṣā. The manuscript dates from the $15^{\text {th }}$ century, a time when Kashmir was firmly under the rule of the Sultans, but when Shaiva traditions were still common. The style of the work is lyrical kāvya, with elaborate descriptions of battle, love games, ladies of the court and warriors. In this article we look at one more aspect for which this story is relevant, i.e. the linguistic evidence that the text offers, in particular with respect to the evolution of the Kashmiri language. As one of the few surviving texts in Old Kashmiri, it offers a lot of information on the Early New Indo-Aryan stage between Apabhramśa and Modern Kashmiri. One of the features will be particularly emphasized: Modern Kashmiri shows elaborate use of pronominal suffixation. Tracing the evolution of Kashmiri in a text which unites features of Prakrit, Apabhramśa and Old Kashmiri can give an idea to when and where this phenomenon has originated, and how it is related to other grammatical features of Kashmiri.

A manuscript of the BK, composed in sharada script, is kept by the Bhandarkar Oriental Society, collected by Bühler in 1875-1876 (1877: 90) and dated 1658 (1020 Hijrā). In the colophon, the last complete verse of the manuscript, it is mentioned that the work has been completed in the $26^{\text {th }}$ year of the reign of Zain-Ul-Abidin, who reigned from 1420-1470 (cf. Kachru 1981:14):

śrīzainaullābhadīne narapati racite dharmarājye suśuddhe

șadvimiśe vatsare iha panamet sarase krṣnabāṇāna yuddhe. deśyo avatārabhațte viracon ramaṇi ākhy paśyet siddhe 
bandhā gìrvān bhāṣi aj harivaṃśe bhārateti garuddhe.. 390.

'Composed in the bright reign of the Lord Sri Zain-Ul-Abidin, after we have greeted here the $26^{\text {th }}$ year, is the lyrical work on the battle between Krishna and Bana. Avatārabhațta has told this love story in the local language after seeing the Siddhas. This story was told for the first time in the Harivamsa and the well-known Mahabharata.

We can safely assume that the work dates from the $15^{\text {th }}$ century. The time under Sultan Zainul-Abidin was a prosperous period, and it is possible that Avtar Bhatt resided at court (Mukherjee 1999).

The article is structured as follows: in the first section, I will shortly summarize the story as told in the $B K$, and situate it compared to the different versions of the story. The second section focuses on Old Kashmiri and the sources thus far found which give us evidence on the language. The third section is a short grammatical outline of the features we distinguish in the language of the $B K$, and the fourth section focuses on one of these features, i.e., the presence of pronominal suffixes in the $B K$.

\section{The Old Kashmiri Bānāsurākathā}

The Bānāsurakathā tells a story which occurs in the Purānas in various versions. One of the best known is the version from the Harivamśapurāna, but it is also found in the Viṣnupurāna, the Bhāgavatapurāna and in the Śivapurāna (cf. Sahai 1978, Couture 2003). The content of the story is as follows : the demon Bāna receives a boon of Shiva, on account of his great efforts in meditation. He was made invincible and received a 1000 arms and many divine weapons, but now that he has no opponents left, he feels that his 1000 arms are useless. His wish is to receive a great fight. Shiva agrees to this. When Bāna tells his minister Kumbandha 
about his conversation with Shiva, lightning strikes and his standard is broken; this is the sign that Bāṇa’s fight will start. Bāṇa’s daughter Ușā witnesses Parvati and her husband enjoying themselves at the bank of the river, and is envious of their amorous play. Parvati tells her that Ușā will have a dream of the man she will marry. Ușā dreams of making love with Aniruddha, Krishna's grandson, in such a way that she cannot do anything else but to pursue him in real life. Her friend, the apsaras Citrālekhā, draws a picture of the demons, gods and men, and Ușā recognizes Aniruddha as the man from her dreams. Citrālekhā then goes to Dwarka, Krishna's hometown, and persuades Aniruddha to follow her back to Bāṇa’s city Sonitapura. Aniruddha has also seen Uṣā in a dream, and willingly goes with Citrālekhā. However, upon finding out of his daughter's situation, Bāna is not pleased, and fights with Aniruddha. Despite Aniruddha's great strength, Bāṇa manages to throw snake-bonds on Aniruddha, thus imprisoning him. Krishna, Aniruddha's grandfather, hears from Aniruddha's capture through the wise man Nārada. He leaves for Sonitapura, seated on Garuda and accompanied by his army. This is the start of the great battle which Shiva promised Bāṇa. Krishna defeats Bāṇa, but spares him after pleas from the goddess. He does cut off 800 of Bāṇa’s 1000 arms. In the end, Krishna leaves for Dwarka, together with Aniruddha and Ușā.

Avtar Bhatt's version follows the most extended version of the story as found in the Harivamsapurāna. (Couture 2003). However, it is clearly a kāvya work in style, and a lot of the attention goes to elaborate descriptions of the love story between Ușā and Aniruddha. Ușā's love sickness after the dream is described in 40 verses, and Aniruddha's longing for Ușā is also described extensively. Multiple verses have the phrase come to me my love, and Ușā's plea to keep Aniruddha safe and not drawn into battle is also painstakingly detailed in description.

2. The Bānasurakathā in the literary tradition of Kashmir 
The literary tradition in Kashmiri starts with one of the oldest text in our possession from the Kashmir area, the historical chronicle Rājatarangini written by the historian Kalhana. The work is written in Sanskrit, and Stein (1900: 6) dates the completion of the work in 1149 (cf Kachru 1981: 2). The first traces of the Old Kashmiri language are found in the Chummasaṃkețaprakāśa (also Chummā Sampradāya), by Niśkriyānandanātha (cf. Toshkhani 1975, Kachru 1981:14, Rastogi 1979, Shauq 1997, Sanderson 2007: 333). According to Toshkhani (1975), this text dates from the $11^{\text {th }}$ or $12^{\text {th }}$ century, and is attributed to the Shivaite tantric tradition (cf. Rastogi 1979), which was the dominant tradition in Kashmir at that time (cf. Kachru 1981:9). Shauq (1997) considers the text as important for the Trika Shaivite tradition, and dates it earlier, even in the $9^{\text {th }}$ or $10^{\text {th }}$ century. The Chummā Sampradāya consists of a number of Kashmiri aphorisms or quatrains, with a Sanskrit commentary. However, the linguistic information that can be deduced from the few sentences in Old Kashmiri is scant. The language is very close to Sanskrit, except for some phonetic specificities, and one cannot actually speak of sentences. A finite verb is often missing. A few examples given by Sanderson (2007: 334-335) are for instance:

maccī ummacī > Skt: mattikonmattikā ('she, mad and free of madness')

athicì thiti > Skt: asthityā sthitih ('stasis through cessation of stasis')

The language is identifiable as Old Kashmiri because of some phonological changes: the continuing palatalization of the dental sounds $(t(t)>c(c), t y>c)$, (this phenomenon is already observable in the Prakrit stage, cf. Pischel 1900, Sanderson 2007: 334), the typical Kashmiri preference for the $-u$ - sound ${ }^{1}$ and the consonant clusters which become simplified but retain the aspiration $(s t h>t t h>t h$, Grierson 1911). With regard to verbal morphosyntax, there is

\footnotetext{
${ }^{1}$ Yet the difference with the Apabhraṃśa from the Kashmir area is here unclear, as this Apabhramśa also prefers $-u$ as the ending of the nominative and accusative singular, in masculine and neuter gender (Grierson and Barnett 1920: 133, Sanderson 2007: 334).
} 
not much information one can derive of these few attestations. There are some aphorisms which contain a verb, eg. rami ekāyanu 'he who is the one ground, plays', and asphura ulati 'radiance reverts into non-radiance' (Sanderson 2007: 335-336). The verb ram- means 'to play', the infinitive in Modern Kashmiri is ramun. It derives from an identical form in Sanskrit, ram., ramate. The ending $-i$ of rami and ulati stands for the third person present, and seems to be derived from Sanskrit -ti (cf. Toshkhani 1975, Sanderson 2007: 336). The origin of $u l$. for 'revert' is unknown, but is related to Modern Kashmiri wultun 'to revert, to turn back' by Sanderson (2007: 337). The use of the converb ending on -et(a), Modern Kashmiri -ith, is already attested, e.g. praghateta 'after rubbing' (Toshkhani 1975: 214). ${ }^{2}$

Apart from these specimens, there are three longer texts that comprise a much richer sample of Old Kashmiri: the Mahāñāyaprakāśa (MP) by Siti Kantha, the Bānasurakathā by Avtar Bhatt and the Lallāa-Vakyāṇi, by Lallā. Of these three, the Lallā-Vakyāni is the best studied. Lallā was a poetess and a Bhakti devotee, of whom it is generally accepted that she lived by the end of the $14^{\text {th }}$ century (Grierson and Barnett 1920: 1, Sanderson 2007: 302, Kachru 1981:15, Shauq 1997). The Lallä-Vakyāni is a collection of $v \bar{a} k h s$ or short poems written in a Kashmiri which is perfectly understandable even today. Grierson and Barnett (1920) collected her verses, and edited and translated them to English and to Modern Kashmiri.

Lallā's vākhs were not written down, and have been recorded by Grierson at the start of the $20^{\text {th }}$ century. The modernity of the language was so surprising that an explanation was sought

\footnotetext{
${ }^{2}$ The full list of aphorisms from the Chumma Sampradāya given by Toshkhani (1972) is: bhāva sabhāve sava avināsí sapana sabhāvana vi uppatra te aj niravadhi agama prakāśī idassa dișți kācivipacchanna vigalani śanni āśuṇna svarūpā vividha padārtha sāthu kavaleta àsyu citi sadā nīrūpā viccī vijū virth praghațeta
} 
for it. Shauq (1997) mentions the great evolution in the language between the Chumma's and Lallā's $v \bar{a} k h s$, which perhaps explains his earlier dating of the Chumma's in the $9^{\text {th }}-10^{\text {th }}$ century instead of in the $11^{\text {th }}-12^{\text {th }}$. He mentions the appearance of a broader spectrum of vowels, in particular the high central and mid central vowels, a far going palatalization, a developing case system, and the appearance of the intricate Kashmiri system of verbal concord (Shauq 1997: 217). According to Grierson and Barnett (1920: 7), the oral delivery method explains the nature of the language; the language has been adapted, and has changed to Modern Kashmiri, except for some archaic vocabulary:

Lallā's songs were composed in an old form of the Kāshmīrī language, but it is not probable that we have them in the exact form in which she uttered them. The fact that they have been transmitted by word of mouth prohibits such a supposition. As the language changed insensibly from generation to generation, so must the outward form of the verses have changed in recitation. But, nevertheless, respect for the authoress and the metrical form of the songs have preserved a great many archaic forms of expression. (Grierson and Barnett 1920: 7)

However, in the same introduction, they also mentions that with oral delivery, the language hardly changes, since one orator takes the text literally over from the previous one.

The reciters, even when learned Paṇdits, take every care to deliver the messages word for word as they have received them, whether they understand them or not. (Grierson and Barnett 1920: 3).

The question with regard to the modernity of the language used in the Lallä-Vakyanni is particularly relevant when one takes a look at another manuscript, i.e. the Mahānāya-Prakāśa. The Mahānāya-Prakāśa is a philosophical treatise of tantric Shivaism, completely written in 
Old Kashmiri, but with a commentary in Sanskrit (Sanderson 2007: 302-303, edited as Shastri 1918). Grierson (1929: 73-76) dates the Mahānāya-Prakāśa around the end of the $15^{\text {th }}$ century, which means, after Lallā. Others believe that it is older, for instance Chatterji (1963: 25) and Toshkhani (1975) situate it in the $13^{\text {th }}$ century (Kachru 1981: 14), Shauq (1997) mentions the $12^{\text {th }}-13^{\text {th }}$ century, and Sanderson (2007: 305) rather argues for the early $11^{\text {th }}$ century, showing that Kashmiri was already a language at that age by quoting Kashmiri terms used in accounts of travellers and historians (Sanderson 2007: 302-305). The features of the language of the Mahānāya-Prakāśa seem definitely older than the languages of Lallā's vākhs, in particular because of the presence of Sanskrit. There is a mix of Sanskrit, Apabhramśa and Kashmiri forms.

The Sanskrit version of the following verse (MP XII, 6) shows that the Old Kashmiri language is still very close to the more literary Sanskrit language (Grierson 1929: 76). There is no remarkable influence of Persian or Arabic. Grierson (1929: 76) also gives a Modern Kashmiri translation. The Sanskrit origin is still clear, but the sound changes clearly indicate Kashmiri.

\author{
Old Kashmiri original \\ nitya samādhāne dalavāne \\ caryācarya-kame ukkișta \\ lauki lokottara vasavāne \\ ehu kamathu bhajīva nayaniștha
}

Sanskrit

nitya-samādhānena adolāyamānāḥ

caryācarya-krameṇa utkṛștāh

loke lokottare vasantah 
imam eva kramārthaṃ bhajata (yūyam he) nayanișthāḥ

\author{
Modern Kashmiri \\ něth samādön aḍlawān \\ tsaryātsarěkam wukkiśt \\ lūk lükattar wasawan \\ yihuy kamoth baziv nayĕniśțh
}

\begin{abstract}
'Ye who are stable by constant meditation, ye who are elevated by (following) the order of due observance, ye who dwell in this world and the next, following the right path, serve ye this, the only object of pursuit.'
\end{abstract}

The simplification of the sounds is very obvious $(t k r>k k)$, just like the shortening of the case forms (instrumental $-e<-e n a$ ). Locative case is $-i$, as in Prakrit (cf. Pischel 1900). ehu is preferred instead of imam, deriving from the locative eșu. The Kashmiri and Apabhramśa influence is visible on the preference for $-u$ sounds, such as in ehu kamathu, lauki. In the imperative form bajīva the Kashmiri imperative ending - $i v$-is already quite clear.

Another verse of the Mahānāya-Prakāśa (XIV, 1), translated by Sanderson (2007: 299), shows the Sanskrit-like nature of the MP language again.

pāveta ihu/iha kamu pabhusa pasāde

śitikañthasa gata jammu kitāthu.

tena mi mahajana khalitamasāde

te mārāve mahanayaparamāthu.. $1 .$.

'Since he has mastered this Krama by the grace of the lord the human birth of Shitikantha has fulfilled its purpose. Therefore I [have turned to the composing of 
this work and thus] enabled the pious too to attain *without error* (?) awareness of the true nature of the Mahayana.'

Toshkhani (1975) as well emphasizes the Sanskritic nature of the Mahānaya-Prakāśa, in combination with Apabhramśa forms. ${ }^{3}$

From a first glance, the language of the Bānāsurakathā is closer to that of the MahannayaPrakāśa than to the Lallā-Vakyāni. According to Toshkhani (1975: 232), at first sight it seems that the language of the Mahānaya-Prakāśa is older than the language of the Bānāsurakathā. However, in comparison with the Bānāsurakathāa, the language of the Mahānaya-Prakāśa is stylistically much denser, and follows a more archaic register. Since one text is esoteric, and the other one is poetic kāvya, style should not be confused with language. Toshkhani (1975: 232) asks to compare the following verses, $M P 215$ and $B K 32$, and argues that the language is identical.
tavyu ādivanna kuharānabhu udayo
taru ạ̣ga lagga pavanātrī ama.
abhaya nippariśā pāvaku vapyo
sedu salila àśätrī bhūma.. (MP 215)
śuneta vano kummāṇ̣̣e bānas
anot mañget kit vināśa
yuddha mahādussaha e pānasa tsal

\footnotetext{
${ }^{3}$ He gives the following verses as examples:

devata akk kiśi paru rāci

jaga ghae-mairu makșet

nanta śatta gāsak nerāji

śamavātrī āśayatakṣet (MP 213)

yasu yasu jantusa samvida yasa yasa

nīla pīta sukha: dukha svarūpa

udayisa datta samāṇ̄ samarasa

kama kampana tasa-tasa anurūpa (MP 312)
} 
devā aṃtha vayan mā māṣ (BK 32)

'After hearing this, Kummand spoke to Bāṇa: What have you brought [upon us] by this desparate pleading. The fight will be very painful, com'on, let us save ourselves. God, don't say such things/don't speak in such a way.'

Toshkhani lists a few differences between the language from the $M P$ and from the $B K$ in these verses. In general, there are more Apabhramśa/Prakrit forms in the $M P$ verse, e.g. adivanna, amgalagga, üma, and more tatsammas, e.g. ubhay, salila, udayo. On the other hand, the Kashmiri genitive form already occurs, eg. pavānaṇi (of the wind), āśānī (of hope). In the $B K$, he discerns a greater resemblance to Modern Kashmiri, but considers this a stylistic, not a diachronic, variation. Kashmiri words in the $B K$ are the verbs vano 'he spoke', anot 'you have brought', the converbal form manget, and the objective forms bạnas and pānas. Another typical Kashmiri feature is the introduction of the sibilants, e.g. $c$ becomes $t s$. However, there are still many Sanskrit words in this verse of the $B K$, such as $y u d d h$, 'battle' mahadussaḥ 'great pain', vinaśa 'desperation'. The MP has a preference for the endings $-\bar{a}$,$i$, plurals with an identical form to the singular, or endings on $-\bar{a} n a$, whereas the $B K$ prefers $-a$ for Sanskrit feminine forms in $-\bar{a}$, and $-a$ for the endings $-i$ and $-e$. Typical in Modern Kashmiri, in the $B K$, the sound $-e$ changes into $-i$. Other typical Kashmiri forms found in the $M P$ as well as in the $B K$ are $-t y$ - which changes to $-c c-,-r$ - to $-i-$, the consonant $r$ disappears or merges with the following consonant (eg. $-r n$ - becomes $-n n-$ ).

Table 1 Consonant changes in the Bāṇāsurakathā and the Mahānaya-Prakāśa

\begin{tabular}{|l|l|}
\hline$V c V, V d V$ & $V y V$ \\
\hline$t h$ & $d h$ \\
\hline$-t$ & disappears \\
\hline$m$ & $v$ \\
\hline
\end{tabular}




\begin{tabular}{|l|l|}
\hline$k t, p t$ & $t t$ \\
\hline$n m, h m$ & $m m$ \\
\hline$d y, d h y$ & $j j$ \\
\hline$j v$ & $j$ \\
\hline$s k h$ & $k h$ \\
\hline
\end{tabular}

Irregarding the register in which both texts are written, from the few verses that have been analyzed in the literature, the language of the Mahānaya-Prakāśa seems to be the older one, justifying Sanderson's earlier dating in the 11th century. The text is hermeneutic and has not yet been translated to English or any modern Indo-Aryan language, which makes it difficult to perform a linguistic analysis of it. Moreover, since it is a philosophical treatise, few constructions with first and second persons are expected to occur. The $B K$, on the other hand, lends itself to linguistic analysis, as it is the poetic rendition of a heroic tale, with dialogue and interaction between the main protagonists. Toshkhani (1975) is a complete translation in Hindi. The translation is preceded by a short grammatical introduction, based on the attestation of the forms in the text.

3. Some grammatical features of the language of the Bānāsurakath $\bar{a}$

The verbal conjugation in the Old Kashmiri of the $B K$ is as follows. Imperatives end on the stem, for plurals $-e v /$-en is added. Present participles end on -and, or on the Modern Kashmiri form $-\bar{a}(a) n$. Toshkhani (1975) distinguishes two classes of conjugation in Old Kashmiri. The first one is used for intransitive and transitive verbs.

Table 2 Class 1 conjugation in Old Kashmiri

\begin{tabular}{|l|l|l|l|l|}
\hline & M.SG & F.SG & M.PL & F.PL \\
\hline
\end{tabular}




\begin{tabular}{|l|l|l|l|l|}
\hline 1 & $-o s /-u s$ & $-\bar{\imath} s /-\bar{u} s$ & $-e$ & $-a i$ \\
\hline 2 & & & & \\
\hline 3 & $-a /-u /-o$ & $-i$ & $-e$ & $-\bar{a}$ \\
\hline
\end{tabular}

The second class is only used with past intransitive verbs, and is only attested for singular forms.

Table 3 Class 2 conjugation in Old Kashmiri

\begin{tabular}{|l|l|l|}
\hline & M.SG & F.SG \\
\hline 1 & $-m a$ & \\
\hline 2 & $-y a$ & $-i s$ \\
\hline 3 & $-s a$ & \\
\hline
\end{tabular}

Past transitive verbs agree with the object, and pronominal suffixes referring to the object as well as to the ergative subject may be added.

The formation of the future tense is as following: the ending for the $1^{\text {st }}$ and $2^{\text {nd }}$ person is $h$, sometimes changed to $-a$ for $1^{\text {st }}$ person. The third person ending is $-i$, and the plural ends on $-v /-o$. The converb ends on $-e t$.

The following table gives the present tense conjugation of the copular verb 'to be':

Table 4 Present tense conjugation of the copular verb

\begin{tabular}{|c|c|c|c|}
\hline & M.SG & F.SG & PL \\
\hline 1 & $k s ̣ o s$ & kșis & kṣe \\
\hline 2 & $k s ̧ o(h)$ & kșih & kșevu/kșiv \\
\hline 3 & kșo/chu & & kși/kșo \\
\hline
\end{tabular}


The initial combination $k s+$ is unlike the expected of $c c h$ - or $-c h$, which would derive from the Prakrit stem acch- (Hock 1982) (and which is still used as copular in Bangla). The third person singular form $c h$ - is attested as well, but is not so frequent. The similarities with the Modern Kashmiri chu conjugation are clear, and this also pertains to the past tense forms. The stem form of the copula in the past is $\bar{a} s$., first singular $\bar{a} s o s$, pl. $\bar{a} s e$. For futures, the first singular is $\bar{a} s$, first plural $\bar{a} s \bar{a}$. To all these forms, pronominal suffixes can be added.

With regard to nouns, the case marking pattern of Modern Kashmiri starts to develop, but it is not yet fully completed. For instance, the case ending for the ergative and instrumental is $-e$, feminine $-i$. The genitive is $-a s$ or $-\bar{a} n i$.

Table 5 Case marking in Old Kashmiri (attested forms in the $B K$ )

\begin{tabular}{|l|l|l|l|l|}
\hline & M.SG & M.PL & F.SG & F.PL \\
\hline NOM & & & & \\
\hline ERG/INS & $-e$ & & $-i$ & \\
\hline OBJ & $-s /-a s$ & $-n /-a n y$ & $-n /-y i$ & $-n /-a n /-a n y ~$ \\
\hline ABL & $-a /-u$ & & & \\
\hline LOC & $-e /-i$ & & & \\
\hline GEN & $-a s /-a n n i$ & & & \\
\hline
\end{tabular}

Modern Kashmiri formally distinguishes a nominative, ergative, objective and ablative case. Though there are intricate phonological changes (Grierson 1911) which make the case marking sometimes rather opaque, and though there is overlapping of case endings to a great extent, inflectional case marking has not disappeared in Kashmiri. On the contrary, compared to the Early New Indo-Aryan stage of Kashmiri, Modern Kashmiri seem to have reinforced case marking.

Table 6 Case marking in Kashmiri (based on Koul and Wali 2006: 32)

\begin{tabular}{|l|l|l|l|l|}
\hline & M. SG. & M. PL. & F. SG. & F. PL. \\
\hline
\end{tabular}




\begin{tabular}{|l|l|l|l|l|}
\hline NOM & - & - & - & - \\
\hline ERG & $-a n /$ palat. & $-a v$ & $-i /-a n$ & $-a v$ \\
\hline OBJ & $-a s /-i s$ & $-a n$ & $-i$ & $-a n$ \\
\hline ABL & $-i /-i$ & $-a v$ & $-i$ & $-a v$ \\
\hline
\end{tabular}

This evolution in Kashmiri stands in contrast with the Central Indo-Aryan languages such as Hindi and Punjabi, which have developed an extensive system of case marking with postpositions. In Kashmiri, postpositions are predominantly used for local cases.

4. The use of pronominal suffixes and V2 word order in the Bānāsurakathā

Modern Kashmiri shows a frequent use of pronominal suffixation, an a-typical feature of Modern Indo-Aryan languages. The phenomenon of pronominal suffixation entails that pronominal main arguments are indicated as markers on the main verb. For instance, in the following example, the suffix $-s$ - refers to the first person subject argument, $-(a) n$ - refers to the patient/direct object argument, and $-(a) v$ is the second person recipient argument.

$$
\begin{aligned}
& \text { soz-ān chu-s-an-av } \\
& \text { send-PTCP.PRS AUX.PRS.M-1SG-3SG-2PL } \\
& \text { 'I am sending him to you.' }
\end{aligned}
$$

In Modern Kashmiri, one has the option either to use these pronominal suffixes, or to mention the pronominal arguments explicitly. All nominative pronominal arguments, however, must be marked on the verb, and all second person arguments as well.

There are three types of pronominal suffixes in Kashmiri, all of which related to the case marking of the pronouns they refer to. For convenience, they are called nominative, ergative and objective suffixes, according to their main function of respectively referring to 
nominative arguments, ergative arguments, and (in)direct object arguments. Interestingly, the ergative suffix is used to refer to the ergative argument of a past transitive construction, but this paradigm of suffixes also has a second function. The ergative suffixes can also refer to the direct object of an imperfective construction, when that direct object is in the nominative case. The term "ergative" suffix is as such deficient, but will be used in lack of a better suited terminology.

Table 7 Pronominal suffixes in Modern Kashmiri (based on Koul and Wali 2006: 117)

\begin{tabular}{|c|c|c|}
\hline & SG & PL \\
\hline \multicolumn{3}{|c|}{ NOM } \\
\hline 1 & $-S$ & I \\
\hline 2 & $-k h$ & $-v(i)$ \\
\hline 3 & I & I \\
\hline \multicolumn{3}{|c|}{ OBJ } \\
\hline 1 & $-m$ & I \\
\hline 2 & $-y i$ & $-v(i)$ \\
\hline 3 & $-S$ & $-k h$ \\
\hline \multicolumn{3}{|c|}{ ERG } \\
\hline 1 & $-m$ & I \\
\hline 2 & $-t h$ & $-v(i)$ \\
\hline 3 & $-n$ & $-k h$ \\
\hline
\end{tabular}

It has been argued that pronominal suffixation in Kashmiri is a remnant of the Vedic system of pronominal cliticization (Emeneau 1964). However, Vedic clitics are not suffixed to a verb and were used much more freely in the sentence, often taking the traditional clitical 
position after the first word of a clause (cf. Wackernagel's law, Wenthe 2012). Consider the following example from Wenthe (2012: 44):
sá
$t v \bar{a}$
vármaṇo
mahimá̀
pipartu
that.NOM.SG you.ACC.SG shield[M]GEN.SG
might[M]NOM.SG cross.PRS.IMP.3SG
'Let the might of the shield help you through.'

Note that $t v \bar{a}$ is here the enclitic form of the second person singular. It is in the second position, and does not carry the Vedic accent. The position and the independence of the clitic is totally different from the Kashmiri pronominal suffixes. Nevertheless, formally, there is a certain similarity between the Kashmiri pronominal suffixes and the Vedic enclitics, of which the paradigm is given in the following table. For instance, $-m$ is typical for first person, and $t(h)$ indicates the second. However, this is a general similarity found in most Indo-Aryan languages, and these sounds are also found in the Vedic full pronouns. The crosslinguistically most common source of person markers are independent pronominal forms, so the formal similarity between the enclitics and the pronominal suffixes is expected, but this does not mean that there is a direct historical relationship between the two paradigms.

Table 8 The Vedic enclitics (Macdonnell 1916)

\begin{tabular}{|l|l|l|l|l|l|l|}
\hline & ACC & & & DAT/GEN & & \\
\hline & SG & DU & PL & SG & DU & PL \\
\hline 1 & $m \bar{a}$ & nau & nas & me & nau & nas \\
\hline 2 & $t v \bar{a}$ & $v \bar{a} m$ & & te & vàm & \\
\hline
\end{tabular}


Since pronominal suffixes are not used in Apabhramśa, the question is when and where they first occurred in Kashmiri. If we look at Lallā's verses (Grierson and Barnett 1920: 36) ${ }^{4}$, we notice that the suffixes are already fully functional:

\section{shiv gur ${ }^{u}$ töy keshĕv palānas \\ brahmā pāyirěn wŏlasěs \\ yogī yoga-kali parzāněs \\ kus dev ashwawār pĕțh cedẹs}

'Shiva is the horse. Zealously employed upon him, the saddle is Vishnu, and, upon the stirrup, Brahmā. The yogi, by the art of his yoga, will recognize him who is the god that will mount upon him as the rider.'

The verbal forms wŏlasĕs, parzānĕs and cedĕs are future tense forms in the third person singular, to which an objective third person suffix is added (but see Grierson and Barnett 1920: 219 for wŏlasěs). The use of a pronominal suffix renders the translation: 'is zealously employed upon him', 'will recognize him' and 'will mount upon him'.

The language of Lallā is very close to Modern Kashmiri, and the use of pronominal suffixes confirms this. One needs to go back to earlier texts to find the very first attestations. Pronominal suffixes are found in the Kashmiri of the $B K$. Toshkhani (1975) gives the following overview, and I added $-y$ as an objective suffix for the second person, based on its attestation in the text.

Table 9 Pronominal suffixation in Old Kashmiri

\begin{tabular}{|l|l|l|l|l|}
\hline & NOM & ERG & \\
\hline
\end{tabular}

\footnotetext{
${ }^{4}$ The transcription is taken over from Grierson and Barnett (1920).
} 


\begin{tabular}{|l|l|l|l|l|}
\hline & SG & PL & SG & PL \\
\hline 1 & $-s$ & & $-m$ & \\
\hline 2 & $-k h$ & $-v$ & $-t h$ & $-v$ \\
\hline 3 & $-(n)$ & $-k h$ & $-n$ & $-n /-h$ \\
\hline & ACC & & OBJ & \\
\hline 1 & SG & PL & SG & PL \\
\hline 2 & $-m$ & & $-m /-s$ & \\
\hline 3 & $-t h$ & $-v$ & $-y$ & $-v$ \\
\hline
\end{tabular}

Toshkhani (1975) identifies pronominal suffixation as an innovation opposed to the Mahānaya-Prakāśa. However, in this text, pronouns in general occur only rarely, since it is a philosophical treatise without much opportunity to include speech act participants.

Toshkhani (1975) discerns four paradigms of suffixes in the $B K$. Just as in Modern Kashmiri, the ergative suffixes are identical to those used to refer to first and second pronominal objects of imperfective constructions (accusative). The difference between the ergative and accusative paradigms with the objective paradigm is only noticeable for the second person singular, which is -th for the ergative and accusative, and $-y$ for the objective.

Pronominal suffixation in Kashmiri seems to be a language-internal development rather than a feature that has been passed on from an ancestral language spoken at least more than 1000 years before the first Old Kashmiri manuscripts. In the Bānāsurakathā, there is no evidence of enclitic forms of the pronoun which occur in the second position of a clause. On the contrary, the pronominal paradigm has already been simplified, and there is only one form per pronoun (though there is variation in spelling, and there are Prakrit and Sanskrit forms which have marked occurrence). The pronominal paradigm in Old Kashmiri looks as follows : 
Table 10 Pronominal paradigm in Old Kashmiri (Toshkhani 1975, on the basis of the forms attested in the $B K$ )

\begin{tabular}{|c|c|c|c|c|c|c|}
\hline & 1SG & $1 P L$ & $2 \mathrm{SG}$ & 2PL & 3SG & 3PL \\
\hline NOM & bu/bhu/ma & asi/ase/aso & $t s \bar{u} / t \bar{u}$ & & $s u / s o, s \bar{a}$ & $\begin{array}{l}\text { te/tem, } \\
\text { ten } \bar{a}\end{array}$ \\
\hline OBL & $m i$ & asi & tsī/tsiye & tusi & soye, sāy & $\begin{array}{l}\text { temay, } \\
\text { tenāy }\end{array}$ \\
\hline GEN & $\begin{array}{l}\text { myano/myanes/ } \\
\text { myane/myis }\end{array}$ & saṃnī & $\begin{array}{l}\text { tsyano/ } \\
\text { tsyana }\end{array}$ & & tas/tassa & \\
\hline INS & & & & & tena & \\
\hline ABL & & & & & $t \bar{a} s \bar{a} m$ & \\
\hline & & & & & teyu, teyi & \\
\hline
\end{tabular}

Sanskrit derived forms of demonstrative pronouns also occur often, e.g. $e h u, e h, e$ derived from Skt. eșa, and i, em, eyam, possibly derived from Skt. idam.

The following examples are all from the $B K$ and illustrate the use of pronominal suffixation in Old Kashmiri.

hara asi-sa

Shiva smile.PST-3SG

'Shiva smiled at him.' (BK 21)

komāra haro-ṇa-sa

$\operatorname{girl}[\mathrm{F}] \mathrm{NOM} . \mathrm{SG} \quad$ take.PST-3SG-3SG

'He took the girl.' (BK 59) 
Both verbs above show the objective third person suffix $-s$, asisa and haronasa. The subject of asisa is the proper noun Hara, whereas the subject of haronasa is not independently mentioned. The third person ergative suffix $-n(a)$ - (cerebralized for phonetic reasons) is used in haronasa. The distribution of the third person suffixes is hence quite similar to that in Modern Kashmiri : they do not seem to occur anaphoric to an independent argument. The following example shows the verb carrying a first person objective suffix attached to the verb $m u s$, , without an independent pronoun. The second example show that the suffix $-m$ is also used to refer to a first person objective, and in Modern Kashmiri only $-m$ remains. The third example shows the use of the independent objective pronoun $m i$, and the verb does not take a suffix.

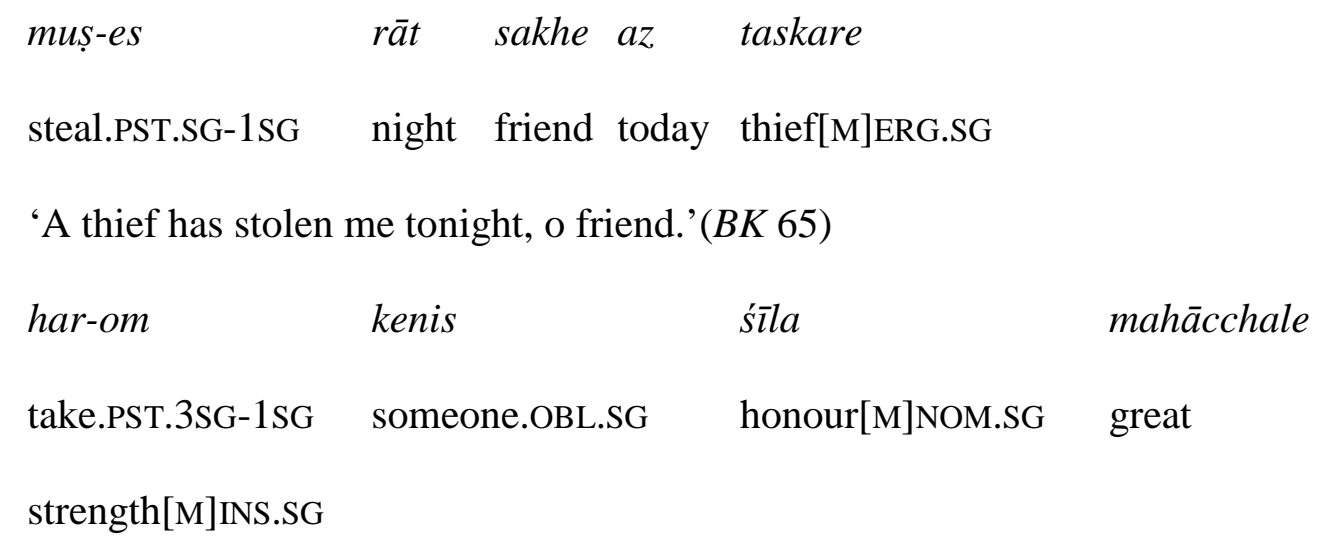

'Someone with great strength took my honour.' (BK 68) mi bāṇa kantha lekhi

I.OBJ.SG Bana[M]NOM.SG throat[M]NOM.SG scratch.FUT.3SG

'Bana will cut my throat. (...cut me the throat)' (BK 74)

The second person suffix in Old Kashmiri has not reached the degree of obligatoriness that it has in Modern Kashmiri. The following example from the $B K$ is a construction with a second person overt subject tsiye, where the second person suffix is absent. The first person indirect object, on the other hand, is only indicated on the verb form by means of the suffix $m a$ and is not expressed with an overt pronoun. 
$\begin{array}{lll}\text { vane-ma } & \text { tsiye } & \text { viśeșa cāratra } \\ \text { tell.PST-1SG } & \text { you.ERG.SG } & \text { special story[M]NOM.SG }\end{array}$

'You told me a particular story.' ( $B K$ 6)

This is not a unique accident, even in the more recent Lallā-Vākyāṇi, Grierson and Barnett (1920: 140) report one example where the second person suffix is absent, though there is an independent pronoun: $t$ se gol 'you destroy', whereas the expected form would be tse goluth. In other words, the rules for the pronominal suffixation of second persons are not so fixed as yet, and even second person suffixes tend to occur in complimentary distribution with an independent argument. For instance, in the following example the verb ditto does not show the objective second person pronominal suffix $-y$, yet the independent pronoun tsi is expressed. All three possibilities are given in these examples: the first example only has the independent pronoun $t s i$, the second one has both the pronoun $t s i$ and the suffix $-y$, and the last one shows only the pronominal suffix $-y$. In sum, though the second person pronominal suffix can be used together with the independent pronoun, there is no fixed rule yet which makes its use obligatory.

$\begin{array}{lclll}\text { vișamo } & \text { kampa } & \text { phanyu } & \text { tsi } & \text { ditto } \\ \text { extensive } & \text { shaking } & \text { snake[M]NOM.SG } & \text { you.OBJ.SG } & \text { give.PST.3SG }\end{array}$

'The snakes gave you massive pain.' (BK 239)

buhiy so kavā tsi // rdayi raṇa-śok

rise.PRS.3SG-2SG this why you.OBJ.SG heart.LOC.SG battle-fear

'Why rises the fear of battle in your heart?' ( $B K 336)$

eniy māraṇ

bring.FUT.3PL-2SG kill.INF

'They will bring you to death.' (BK 121) 
The order of the suffixes is ergative-objective, as in Modern Kashmiri. The objective third person suffix is often mentioned after verbs of speaking, as in the following examples with the verb nigad. Similar constructions with the verb wonun are very common in Modern Kashmiri.

$\begin{array}{lllll}\text { thava tap } & \text { ts } \bar{u} & \text { nigadisa } & e & \text { nātha } \\ \text { stay.IMP.2SG ascetism } & \text { you.NOM.SG } & \text { say.PST.3SG } & \text { this } & \text { Shiva }\end{array}$

'You should continue to do ascetism, said Shiva to him.' (BK 12)

$\begin{array}{llll}\text { dappom } & \text { śailatanayi } & \text { yo mahā viśes } \\ \text { tell.PST.3SG-1SG } & \text { Parvati[F]ERG.SG } & \text { this } & \text { great special }\end{array}$

'Parvati has told me this very special thing.' (BK 77)

From the study of this old text, it is clear that pronominal suffixation was an early feature which occurred together with the first indications of a change from Apabhramśa to modern Kashmiri.

\section{Conclusion}

The language of the Bānasurākathā illustrates an important stage in the history of IndoAryan: it is an example of an Early New Indo-Aryan language. In this language stage, a lot of grammatical changes appear, leading to the case marking and agreement structures of the Modern Indo-Aryan languages (Reinöhl 2016). After an abundance of literature in the Sanskrit and Prakrit languages of the elite, we now find literary texts in the language of the people, such as Avtar Bhatt's Bānāsurakathāa. Because of this discrepancy between the court stylistics and the "simple" language, the $B K$ is not always easy to read. Linguistically, we notice a number of features: the sounds change into their typical Kashmiri mould, with a greater spectrum of vowel sounds and palatalized sounds, the introduction of $t s$ and $z$. The MIA case system shifts into the Kashmiri case marking, and, most interesting, we start to get 
a system of pronominal suffixation. This system is not yet rigidly applied, we do find differentiation and forms are not yet obligatory, yet very clearly, they start to appear. Therefore, this text certainly deserves further study.

\section{References}

Bühler, Georg (1877): Detailed Report of a Tour in Search of Sanskrit MSS. made in Kaśmîr, Rajputana, and Central India. Extra number of the Journal of the Bombay Branch of the Royal Asiatic Society. Bombay and London: Trübner.

Chatterji, S. K. (1963): Kashmiri literature. In Languages and literatures of Modern India. Calcutta: Bengal Publishers. p. 258.

Couture, André (2003): Kṛṣna’’s victory over Bāṇa and goddess Koṭavī’s manifestation in the Harivamía. Journal of Indian Philosophy 31: Pp. 593-620.

Emeneau, Murray (1965): India and Linguistic Areas. In India and Historical Grammar, Publication No. 5. Pp. 25-75. Annamalai: Annamalai University, Department of Linguistics. Republished 1980 in Anwar S. Dil (ed.) Language and Linguistic Area: Essays by Murray B. Emeneau, pp. 126-166, Stanford University Press.

Grierson, George A. (1911): A manual of the Kashmiri language comprising grammar, phrase-book and vocabularies. Oxford: Clarendon Press.

Grierson, George A. (1929): The language of the Mahā-Naya-Prakśa. An examination of Kāshmīrī as written in the $15^{\text {th }}$ century. Memoirs of the Asiatic Society of Bengal 11: Pp. 73130.

Grierson, George G.A. \& Lionel Barnett (1920):. Lallā-Vākyāni, or the wise sayings of Lal Daed, a mystic poetess of ancient Kashmir. London: Royal Asiatic Society. 
Hock, Hans H. (1982): AUX-Cliticization as a motivation for word order change. Studies in the linguistic sciences, 12: Pp. 91-101.

Kachru, Braj B. (1981): Kashmiri literature. Wiesbaden: Otto Harrassowitz.

Kalhạ̣a \& Marcus A. Stein (1961). Kalhaṇa's Rājatarañgin̄i: a chronicle of kings of Kāśmīr. Delhi: Motilal Banarsidass.

Koul, Omkar N. \& Kashi Wali (2006): Modern Kashmiri grammar. Springfield: Dunwoody Press.

Macdonell, Arthur Anthony. (1916): A Vedic Grammar for Students. Reprinted 1993. Delhi: Motilal Banarsidass.

Mukherjee, Sujit (1999): A dictionary of Indian literature: Beginnings-1850. New Delhi: Orient Longman.

Pischel, Richard (1900): Grammatik der Prakrit-Sprachen. Grundriss d. indo-arisch. Philol. u. Altertumskunde Bd. 1. Strassburg: Trübner.

Rastogi, Navjivan. (1979): The Krama tantricism of Kashmir. Delhi: Motilal Banarsidass Toshkhani, Shekhar. (1975): Bāṇāsurakathā. Kashmir University: Unpublished PhD thesis.

Reinöhl, Uta (2016): Grammaticalization and the rise of configurationality in Indo-Aryan. Oxford: Oxford University Press.

Sahai, Sachchidanand. (1978): The Kṛṣna saga in Laos (a study in the Brah Ku'td Brah Bān or the story of Bāṇāsura). Delhi: B. R. Publishing Corporation.

Sanderson, Alexis (2007): “The Śaiva Exegesis of Kashmir.” In: Mélanges tantriques à la mémoire d'Hélène Brunner / Tantric Studies in Memory of Hélène Brunner, edited by Dominic Goodall and André Padoux, Pondicherry: Institut français d'Indologie / École française d'Extrême-Orient. 
Shauq, Shafi. (1997): Medieval Kashmiri literature. In K. Ayyappa Paniker (ed.) Medieval Indian literature. An anthology. Volume 1. Surveys and selections. New Delhi: Sahitya Akademi. Pp. 215-254.

Wenthe, Mark Raymund (2012): Issues in the placement of enclitic personal pronouns in the Rigveda. Unpublished PhD dissertation Athens, Georgia. 